\title{
BELAJAR BERBASIS ANEKA SUMBER DALAM PENDIDIKAN NONFORMAL
}

\author{
B. P. Sitepu*
}

\begin{abstract}
Paradigm shift in education has made significant change in the roles of teacher and student in teaching and learning process. In the new paradigm the student become the axis of teaching and learning process. The student makes the choice in learning objective, learning materials, and learning resources based on his/her learning style. The teacher acts more as a learning designer, learning manager, and tutor. The learning theory development tends to provide the learner with learning skills to enable them to be independent learners to life-long learning. However, the learning theories are mostly discussed in the formal eduacation situation, though the theories are also apllicable for nonformal education. This article discusses how the current learning theories can be implemented in nonformal education. The discussion is limited on the application of learning resources development in early childhood education and learning community centers. The discussion ends with a strong conclusion that resources based learning theory are potential and need to apply in nonformal education under a condition that there should be some changes in the roles of teachers/instructors, learners, and the nonformal institution.
\end{abstract}

Key words: nonformal education, active learning, student-centered learning, teacher-centered learning, resources-based learning

\begin{abstract}
Pergeseran paradigma pendidikan yang antara lain berubahnya kedudukan pembelajar dan pemelajar dalam proses belajar dan membelajarkan. Dewasa ini, pemelajar menjadi pelaku utama dan fokus proses pembelajaran dan pembelajar lebih berfungsi sebagai perancang dan pengelola pembelajaran serta membantu pemelajar yang mengalami kesulitan belajar. Perkembangan teori pembelajaran mengarah pada pembekalan pemelajar untuk mampu belajar secara mandiri sepanjang hayat. Teori belajar dan membelajarkan banyak dibicarakan dalam konteks kegiatan belajar dan membelajarkan di pendidikan formal, padahal teori itu juga berlaku untuk kegiatan pendidikan nonformal. Tetapi bagaimana teori itu diterapkan di pendidikan nonformal merupakan permasalahan tersendiri. Tulisan ini secara khusus membahas penerapan pendekatan belajar berbasis aneka sumber dalam pendidikan nonformal. Oleh karena begitu banyak jenis dan bentuk pendidikan nonformal, pembahasan dibatasi pada pendidikan usia dini (TPA dan KB) dan di PKBM yang menyelenggarakan berbagai kegiatan pembelajaran. Melalui kajian teoretik tulisan ini berkesimpulan bahwa pendekatan belajar berbasis aneka sumber dalam pendidikan nonformal dapat dan perlu diterapkan dengan melakukan penyesuaian peran pembelajar, pemelajar, dan satuan pendidikan nonformal.
\end{abstract}

Kata-kata kunci: pendidikan nonformal, belajar aktif, belajar berpusat pada pemelajar, belajar berpusat pada pembelajar, belajar berbasis aneka sumber.

\section{PENDAHULUAN}

Pergeseran paradigma atas pendidikan antara lain bahwa pendekatan belajar dan membelajarkan dilakukan berpusat kepada pemelajar (student-oriented approach) dengan pengertian pemelajar menjadi pemeran utama dalam proses belajar dan membelajarkan.

\footnotetext{
* Dosen Pasca Sarjana Program Studi Teknologi Pendidikan Universitas Negeri Jakarta
}

Pemelajar secara aktif terlibat mulai dari perencanaan, pelaksanaan, dan refleksi diri untuk memperoleh kemampuan baru. Sementara itu, pembelajar lebih berfungsi sebagai desainer, tutor, dan manajer pembelajaran. Hasil-hasil penelitian di bidang psikologi, pedagogi, dan andragogi antara lain menemukan bahwa masingmasing individu memiliki gaya belajar yang berbeda. Akan tetapi, perbedaan gaya belajar ini tidak menun- 
jukkan perbedaan kemampuan belajar seseorang. Kemampuan yang sama dapat dikuasai oleh masingmasing individu dengan gaya belajar yang berbeda. Berkaitan dengan gaya belajar ini, Gardner (2004) mengidentifikasi ada sembilan jenis kecerdasan (intelegensia). Setiap orang memiliki satu atau lebih jenis kecerdasan yang dominan yang mempengaruhi gaya belajarnya.

Perbedaan jenis, tingkat kecerdasan, serta gaya belajar mengakibatkan sumber belajar yang diperlukan dalam mencapai kompetensi tertentu juga berbeda. Atas dasar kenyataan yang demikian, maka dalam proses belajar dan membelajarkan karakteristik pemelajar secara individu dan kelompok perlu diperhatikan dalam menyediakan sumber belajar. Adanya berbagai ragam gaya belajar menjadi salah satu dasar utama berkembangnya pendekatan belajar berbasis aneka sumber.

Pendekatan belajar beorientasi pada pemelajar memicu berkembangnya strategi dan model belajar yang menempatkan pemelajar dalam posisi sentral dan sebagai pemeran utama yang aktif dalam proses belajar dan membelajarkan, seperti belajar berbasis masalah, belajar kontekstual, belajar kooperatif, belajar kolaboratif, belajar inkuiri, belajar dengan menemukan (discovery learning), dan belajar berbasis pengalaman. Akan tetapi, semua strategi dan model belajar itu akan efektif apabila tersedia aneka sumber belajar yang dapat dijadikan pilihan oleh pemelajar sesuai dengan pengalaman, minat, motivasi, tujuan, dan gaya belajarnya.

Di jalur pendidikan formal, upaya menyediakan aneka sumber belajar dilakukakan secara terencana dengan menyediakan dan mengembangkan perpustakaan, laboratorium, tempat peraktek, serta pusat sumber belajar. Di samping itu, sekolah dapat juga memanfaatkan sumber belajar lain, yang sebenarnya peruntukannya bukan untuk kegiatan belajar, seperti museum, kebun binatang, dan pasar. Dengan tersedianya aneka sumber belajar itu, pembelajar dapat membuat desain pembelajaran yang memberikan kesempatan pemelajar memilih sumber belajar yang sesuai dengan gaya belajarnya.

Kegiatan belajar tidak hanya terjadi di lembaga pendidikan dan juga tidak dibatasi oleh waktu, tempat, dan sumber belajar. Dengan pesatnya perkembangan ilmu pengetahuan, teknologi, dan seni serta munculnya berbagai inovasi di tempat pekerjaan dan perubahan sosial serta budaya di tengah-tengah masyarakat mengakibatkan lembaga pendidikan tidak dapat lagi diandalkan sebagai satu-satunya tempat belajar memperoleh pengetahuan dan keterampilan. Sungguhpun demikian, lembaga pendidikan diharapkan dapat mem- berikan kemampuan belajar (how to learn) dalam arti kemampuan untuk mengetahui apa yang perlu dipelajari, bagaimana cara mempelajarinya, dan sumber belajar apa yang sesuai. Kemampuan ini merupakan kemampuan dasar untuk setiap orang agar dapat belajar secara mandiri sepanjang hayat.

Secara teori dan praktik dibedakan antara belajar berbasis aneka sumber dan membelajarkan berbasis aneka sumber. Yang pertama disebut adalah proses belajar yang memberikan pilihan, kesempatan, dan kemudahan kepada pemelajar untuk mencapai tujuan belajar sesuai dengan gaya belajarnya. Jadi pendekatan ini berorientasi pada pemelajar. Yang kedua disebut adalah proses membelajarkan yang diterapkan oleh pembelajar dengan menyajikan bahan pelajaran menggunakan aneka sumber informasi/ belajar sesuai dengan pertimbangan dan pilihan pembelajar sendiri. Contohnya, untuk mencapai tujuan pembelajaran dalam satu kali pertemuan tatap muka, pembelajar menggunakan metode ceramah, disertai dengan tayangan power point dan diselingi dengan video. Kemudian pembelajar menyuruh pemelajar berdiskusi dalam kelompok sambil mendapatkan informasi tambahan dari internet, dan diakhiri dengan paparan kelompok. Dalam contoh ini, pembelajar membelajarkan dengan menggunakan metode yang beragam. Pemelajar memperoleh pengalaman belajar yang bervariasi tetapi tidak memberikan kesempatan kepada pemelajar untuk menentukan sendiri sumber belajarnya. Pendekatan belajar dan membelajarkan demikian masih menggunakan pendekatan berorientasi kepada pembelajar.

Pendekatan belajar berbasis aneka sumber dapat diterapkan dalam kegiatan pembelajaran di jalur pendidikan formal dan nonformal dengan prinsip yang sama. Di pendidikan formal biasanya pengadaan sumber belajar lebih terencana, tertata lebih teratur, dan cenderung bersifat standar. Sedangkan di pendidikan nonformal pengadaan sumber belajar lebih bervariasi dan banyak tergantung pada kreativitas dan kemampuan pengelolanya. Sementara itu, pendidikan nonformal memberikan lebih banyak kesempatan belajar tanpa batas usia dan diharapkan memberikan lebih banyak kesempatan untuk belajar dari berbagai sumber.

Dalam tulisan ini, kajian dibatasi pada pendekatan belajar berbasis aneka sumber yang berorientasi pada pemelajar di jalur pendidikan nonformal. Pembahasan difokuskan pada bagaimana kemampuan belajar berbasis aneka sumber dilakukan dalam jalur pendidikan nonformal sehingga pembelajar mengetahui dan terampil menentukan apa yang perlu dipelajari, bagaimana mempelajarinya, dan menggunakan sumbersumber belajar apa saja. Kajian dalam tulisan ini di- 
harapkan dapat dijadikan salah satu acuan oleh pembelajar di pendidikan nonformal (guru, pelatih, tutor, dan sebagainya) dalam membelajarkan pemelajar. Di samping itu, diharapkan kajian ini juga dapat memberikan pemahaman kepada pemelajar di pendidikan nonformal bahwa kegiatan belajar itu adalah berkelanjutan dan berlangsung sepanjang hayat dengan menggunakan berbagai sumber belajar.

Sebelum sampai pada kajian lebih lanjut, perlu diketahui terlebih dahulu konsep belajar berbasis aneka sumber, sebagai titik tolak untuk pembahasan lebih lanjut.

\section{KAJIAN TEORETIS}

Pendekatan belajar dan membelajarkan selama ini dibedakakan antara pendekatan berpusat pada guru yang dianggap merupakan pendekatan tradisonal dan pendekatan berpusat pada pemelajar yang merupakan pendekatan yang terbaru. Belajar berbasis aneka sumber dikembangkan atas paradigma pendekatan belajar berpusat pada pemelajar dengan latar belakang sebagai berikut.

\section{Landasan Teoretis}

Dalam perubahan paradigma atas pendidikan, terlihat pergeseran dari belajar berpusat pada pembelajar menjadi belajar berpusat pada pemelajar. Berpusat kepada pembelajar berarti bahwa pada sistem pendidikan tradisonal belajar dianggap pengalihan pengetahuan atau informasi dari pembelajar kepada pemelajar yang menekankan pada isi pelajaran dalam bentuk pengetahuan, keterampilan, atau sikap. Sedangkan dalam belajar berpusat pada pemelajar, belajar menekankan pada proses kegiatan pemelajar dalam mencari dan memperoleh kemampuan baru. Peranan aktif pemelajar ini penting karena pada hakikatnya pemelajar yang membangun pengetahuannya dan pembelajar lebih berfungsi sebagai fasilitator dan tutor dalam proses pemelajar membangun pengetahuannya itu. Pergeseran dari bepusat pada pembelajar menjadi pada pemelajar mengakibatkan peralihan wewenang dari pembelajar kepada pemelajar dalam menentukan (1) apa yang menarik, relevan, atau harus dipelajari; (2) apa tujuan belajarnya; (3) kapan dipelajari; (4) bagaimana mempelajarinya; (5) apa sumber belajarnya; (6) bagaimana cara menilai hasil belajar; dan (7) siapa yang menilainya.

Pengalihan dari pembelajar kepada pemelajar dalam mengambil sejumlah keputusan kegiatan belajar mendasari pemikiran dan konsep bahwa pemelajar memiliki pilihan, terlibat, serta bertanggung jawab dalam kegiatan belajarnya. Dengan demikian maka prinsip yang dianut dalam menerapkan belajar berpusat pada pemelajar menurut Brandes dan Ginnis (1986) ialah (1) pemelajar bertanggung jawab penuh atas kegiatan belajarnya; (2) keterlibatan dan peran serta pemelajar sangat diperlukan; (3) hubungan antar- pemelajar adalah setara dalam membangun pengetahuannya (saling belajar dan membelajarkan); (4) pembelajar berperan sebagai tutor dan narasumber; (5) pengalaman belajar pemelajar menyatu (domain kognitif dan afektif berkembang bersama-sama); dan (6) pemelajar memandang dirinya secara berbeda sebagai salah satu hasil pengalaman belajar.

Belakangan ini, walaupun tidak jauh berbeda dengan prinsip yang dikemukakan Brandes dan Ginnis (1986), Lea dan teman-temannya (2003: 322) merumuskan prinsip belajar berpusat pada pemelajar adalah (1) bergantung pada belajar aktif; (2) menekankan belajar dan memahami secara mendalam; (3) tanggung jawab dan akuntabilitas pemelajar bertambah; (4) otonomi pemelajar bertambah luas; (5) saling ketergantungan antara pemelajar dan pembelajar; (6) saling menghormati antara pemelajar dan pembelajar; dan (7) pendekatan yang bersifat koreksi diri terhadap proses belajar pada pihak pemelajar dan pembelajar.

Di samping pendapat Brandes dan Ginnis serta Lea dan teman-temanya itu terdapat berbagai pendapat lain yang kalau dikaji lebih lanjut dapat disimpulkan, terdapat tiga pendapat yang mengartikan belajar berpusat pembelajar. Pertama, memberikan pilihan kepada pemelajar dalam belajar. Kedua, menekankan pada peran dan tanggung jawab pemelajar yang lebih besar daripada pembelajar dalam belajar berbasis pemelajar. Ketiga, menggabungkan pendapat pertama dan kedua dengan mengatakan bahwa belajar bepusat pada pemelajar adalah memberikan kebebasan kepada pemelajar dalam belajar dan peran serta tanggung jawab yang lebih besar kepada pemelajar daripada pembelajar.

Sungguhpun secara teoretis dibedakan belajar berpusat pada pembelajar dari belajar berpusat pada pemelajar, dalam prakteknya kedua-duanya tidak dapat dipisahkan secara tegas seperti antara hitam dan putih. Kedua pendekatan itu terletak pada garis kontinum dengan pendekatan belajar berpusat pada pembelajar pada satu ujung dan belajar berpusat pada pemelajar pada ujung lain. Dalam proses belajar, kegiatan belajar bergerak antara kedua ujung itu. Dikatakan berpusat pada pembelajar, apabila lebih banyak kegiatan belajar 
terjadi pada rentang yang mendekati titik belajar berpusat pada pembelajar dan dikatakan belajar berpusat pada pemelajar apabila lebih banyak kegiatan belajar terjadi mendekati titik belajar berpusat pada pemelajar. Untuk tujuan belajar atau kondisi tertentu masih diperlukan lebih banyak kegiatan belajar berpusat pada pemelajar. Contohnya, anak usia dini tentu belum dapat diberikan kebebasan dalam menentukan apa yang dipelajari, bagaimana mempelajarinya, serta sumber belajar apa yang dipergunakan. Peranan pembelajar masih diperlukan lebih dominan dengan tidak mengabaikan bahwa dalam hal-hal tertentu pemelajar diberikan kebebasan, misalnya menentukan permainan yang disenanginya serta tempat bermain sambil belajar. Semakin dewasa pemelajar, pendekatan pembelajaran semakin mengarah dan berpusat pada pemalajar.

Salah satu prinsip dalam belajar berpusat pada pembelajar ialah memberikan kesempatan untuk menentukan pilihan tujuan, bahan, metode, dan sumber belajar. Prinsip ini mencerminkan demokrasi, hak, dan tanggung jawab dalam belajar. Sungguhpun demikian, kesempatan menentukan pilihan itu dipagari oleh sejumlah kondisi. Ketika seseorang memilih lembaga pendidikan tempat belajar dan bidang studi atau keterampilan yang hendak dipelajarinya, seseorang sudah memperoleh kesempatan untuk membuat pilihan apa yang perlu dipelajari. Akan tetapi, pilihan itu mempunyai batas-batas, dalam arti tidak dapat memilih lembaga pendidikan dan bidang studi yang tidak ada atau ada tapi tidak terjangakau olehnya. Demikian juga sesudah memasuki suatu lembaga pendidikan, pemelajar menghadapi kurikulum yang sudah memuat disiplin ilmu atau bidang keterampilan yang perlu dipelajari, alokasi waktu, dan beban belajar. Lebih lanjut lagi, jadwal belajar juga sudah ditetapkan oleh lembaga pendidikan. Lalu di mana penerapan belajar berorientasi pemelajar?

Ketika seseorang telah memasuki lembaga pendidikan, kesempatan membuat pilihan itu terjadi ketika diberikan kemungkinan untuk menentukan bidang studi pilihan dan urutan bidang studi untuk dipelajari. Ketika proses belajar dimulai, pembelajar menerapkan pendekatan belajar berpusat kepada pemelajar dalam membicarakan dan menyepakati bersama tujuan belajar, bahan pelajaran, startegi dan metode belajar, serta sumber belajar. Sungguhpun dalam belajar berpusat pada pemelajar, pemelajar diperbolehkan belajar sesuai dengan gaya belajarnya dan menentukan sumber belajar yang sesuai untuknya, kebebasan ini dibatasi oleh ketersediaan sumber belajar yang ada di lembaga pendidikan dan tidak mungkin dipenuhi untuk masingmasing pembelajar. Kebebasan tersebut dapat dilakukan oleh pemelajar di luar lembaga pendidikan.
Pendekatan belajar berpusat pada pemelajar pada intinya memberikan pilihan kepada pemelajar dalam menentukan kegiatan belajar dan pemelajar bertanggung jawab atas kegiatan belajar yang dilakukannya untuk mencapai tujuan belajar. Dalam konteks memberikan kesempatan memilih dan bertanggung jawab itulah, belajar berbasis aneka sumber ikut berperan dan berkembang.

\section{Teori Belajar Berbasis Aneka Sumber}

Belajar berbasis aneka sumber dapat dianggap sebagai pendekatan, strategi, model atau metode belajar. Dianggap sebagai pendekatan belajar, apabila belajar berbasis aneka sumber diberlakukan sebagai pola pikir dalam merancang strategi, model, dan metode belajar. Dapat juga dianggap sebagai strategi, apa bila belajar berbasis aneka sumber belajar sebagai desain besar (grand design) yang melandasi suatu model belajar. Dianggap sebagai model belajar, apabila belajar berbasis aneka sumber dipergunakan untuk menggambarkan komponen-komponen penting dan hubungan antarkomponen dalam belajar. Terakhir, dapat dipergunakan sebagai metode apabila dipergunakan untuk menunjukkan langkah-langkah yang perlu diterapkan dalam melaksanakan belajar berbasis aneka sumber mulai dari awal sampai akhir.

Sebagai suatu pendekatan, belajar berbasis aneka sumber beranggapan bahwa pelaku utama dalam kegiatan belajar adalah pemelajar yang memiliki karakter yang berbeda satu sama lain sehingga memiliki gaya belajar yang juga berbeda untuk menguasai kemampuan/ kompetensi tertentu. Sebagaimana dikemukakan oleh Reigeluth (1987: 1-2), terdapat tiga komponen yang saling mempengaruhi dalam membuat desain pembelajaran yaitu kondisi/ situasi, metode, dan tujuan pembelajaran. Perubahan dalam salah satu komponen ini menuntut perubahan dalam komponen lain apabila proses pembelajaran itu ingin berhasil.

Sebagai contoh, metode pembelajaran yang sama dapat diterapkan apabila kondisi pemelajar dan tujuan pembelajaran adalah sama. Atau tujuan pembelajaran yang sama dapat tercapai apabila kondisi pemelajar dan metode yang dipergunakan adalah sama. Dengan perkataan lain, tujuan dan metode pembelajaran yang sama dapat dapat diberlakukan kalau kondisi pembelajar adalah sama. Cara berpikir yang demikian dapat juga dipakai untuk memberikan saran seperti berikut, kalau kondisi belajar berbeda, sedangkan tujuan pembelajaran adalah sama maka metode pembelajaran yang diterapkan harus berbeda. Atas dasar logika berpikir yang demikian, belajar berbasis aneka sumber beranggapan bahwa karakteristik pemelajar yang berbeda menghendaki gaya belajar yang berbeda 
untuk menguasai kemampuan/ kompetensi yang sama.

Sebagai strategi pembelajaran, belajar berbasis aneka sumber memberikan pemelajar kesempatan memperoleh serta membangun pengetahuannya melalui interaksi dengan berbagai sumber belajar sesuai dengan gaya belajarnya. Startegi ini akan membuat pemelajar aktif dan kreatif dalam merencanakan dan melakukan kegiatan belajar. Apabila belajar berbasis aneka sumber dipergunakan dalam membuat model pembelajaran, maka pembelajar dapat menentukan komponen-komopen belajar yang diperlukan dan hubungan antarkomponen itu, sehingga dapat merancang dan mempersiapkan proses pembelajaran yang sesuai dengan memberikan kesempatan kepada pemelajar memilih sumber belajar dan cara belajar yang sesuai untuk tujuan pembelajaran. Model ini juga bermanfaat ketika pembelajar akan mengevaluasi proses pembelajaran dan melakukan perbaikan untuk pembelajaran berikutnya. Sedangkan menggunakan belajar berbasis aneka sumber sebagai metodologi memungkinkan pemelajar belajar dari upaya pemelajar sendiri berhadapan dengan berbagai sumber informasi sehingga pemelajar memperoleh keterampilan dalam mencari, memilah, memilih, dan menggunakan informasi dalam bidang yang dipelajari.

Campbell, dkk (2009) mendefinisikan belajar berbasis sumber belajar sebagi berikut "Resource based learning is an educational model designed to actively engaged students with multiple resources in both print and non-print format". Campbell, dkk melihat belajar berbasis aneka sumber sebagai model pendidikan, yang berarti lebih luas dari hanya model pembelajaran. Campbell, dkk berpendapat bahwa tujuan belajar berbasis aneka sumber dirancang untuk melibatkan pemelajar aktif dalam belajar dengan menggunakan berbagai sumber baik dalam bentuk cetakan maupun yang bukan dalam bentuk cetakan.

Perlu diketahui bahwa belajar berbasis aneka sumber merupakan pendekatan, starategi, model, atau metode belajar yang tidak tergantung pada teori belajar tertentu. Belajar berbasis aneka sumber dapat dipakai untuk pendekatan belajar yang berlandaskan teori belajar behaviourisme, kognitivisme, konstruktivisme atau aliran lain. Berbagai strategi dan metode belajar yang berkembang belakangan ini seperti belajar inkuiri, belajar berbasis masalah, belajar berbasis proyek, belajar kontekstual, belajar kolaboratif, dan belajar kooperatif, dan blended learning sangat berkaitan dengan belajar berbasis aneka sumber. Masing-masing strategi belajar yang disebutkan itu melibatkan pemelajar aktif dalam proses belajar dan keaktifannya itu akan mencapai hasil seperti yang diharapkan apabila tersedia aneka sumber belajar.

Perlu diperhatikan bahwa pendekatan belajar berbasis aneka sumber berorentasi pada pemelajar dalam arti pemelajar diberikan kebebasan memilih sumber belajar yang sesuai dengan gaya belajarnya untuk mencapai tujuan pembelajaran. Pembelajar dapat saja memberikan berbagai alternatif sumber belajar, tetapi pemelajar yang menentukan sumber belajar yang mana sesuai untuknya dengan tetap mengacu pada kemampuan yang hendak dicapai.

\section{PEMBAHASAN}

\section{Penerapan Belajar Berbasis Aneka Sumber dalam Pendidikan Nonformal}

Pengalaman dalam proses belajar dan membelajarkan serta berbagai penelitian yang dilakukan telah mendorong perubahan paradigma atas pendidikan. Reigeluth (1994: 8) dan Belt (1997) memberikan contoh perubahan itu tidak saja pendekatan yang semula berorientasi kepada pembelajar bergeser kepada pemelajar, tetapi juga ruang belajar yang semula dibatasi oleh dinding, lantai, dan langit-langit, meluas menjadi dunia tanpa batas. Dari waktu belajar yang dibatasi secara ketat dengan jadwal tempat belajar, berubah menjadi belajar tanpa batas waktu dan batas tempat. Kesempatan belajar yang dibatasi dengan rentang umur untuk jenjang pendidikan tertentu menjadi terbuka untuk semua umur dan sepanjang hayat. Sistem evaluasi yang semula berpatokan pada penguasaan bahan pela- jaran, berubah menjadi berpatokan pada penguasaan kemampuan. Sumber belajar yang mengacu pada buku pelajaran kini berubah mengacu pada teknologi informasi dan komunikasi.

Perubahan paradagima seperti yang dikemukakan oleh Reigeluth dan Belt itu bukan merupakan hal yang asing bagi pendidikan nonformal, karena pendidikan nonformal diselenggarakan tanpa batas waktu, tempat, dan usia. Isi pendidikan nonformal juga lebih mengarah kepada keterampilan praktis yang berarti berdasarkan penguasaan kemampuan. Akan tetapi, proses belajar dan membelajarkan yang berpusat kepada pemelajar dengan menggunakan pendekatan belajar berbasis aneka sumber merupakan sesuatu yang belum biasa dilaksanakan di berbagai kegiatan belajar dan membelajarkan di pendidikan nonformal. Para tutor, pelatih/instruktur, dan pamong belajar masih 
mendominasi kegiatan pembelajaran dan berarti masih menggunakan pendekatan tradisional. Penggunaan aneka sumber belajar adalah untuk memudahkan atau membantu pembelajar menyampaikan bahan pelajaran/ pelatihan. Persoalannya sekarang ialah bagaimana menerapkan penerapan pendekatan belajar dan membelajarkan berpusat kepada pemelajar dengan menggunakan aneka sumber belajar di dalam kegiatan belajar dan membelajarkan di jalur pendidikan nonformal?

Pendidikan nonformal di dalam Sistem Pendidikan Nasional di Indonesia berfungsi sebagai bentuk penyelenggaraan pendidikan di luar jalur formal oleh masyarakat atau pemerintah, dapat dalam bentuk terstruktur dan berjenang, untuk melayani kebutuhan masyarakat sebagai pengganti, penambah atau pelengkap pendidikan formal dalam mendukung pendidikan atau belajar sepanjang hayat. Pendidikan nonformal mengembangkan potensi pemelajar dalam penguasaan pengetahuan, keterampilan fungsional, dan pengembangan sikap dan kepribadian profesional. Pendidikan nonformal meliputi pendidikan kecakapan hidup, pendidikan usaha dini, pendidikan kepemudaan, pendidikan pemberdayaan perempuan, pendidikan keaksaraan, pendidikan keterampilan dan pelatihan kerja, pendidikan kesetaraan, serta pendidikan lain yang ditujukan untuk mengembangkan kemampuan peserta didik. Satuan pendidikan nonformal terdiri atas lembaga kursus, lembaga pelatihan, kelompok belajar, pusat kegiatan belajar masyarakat, dan majelis taklim, serta satuan pendidikan sejenis. Hasil pendidikan nonformal dapat dihargai setara dengan hasil program pendidikan formal setelah melalui proses penilaian penyetaraan oleh lembaga yang ditunjuk oleh pemerintah atau pemerintah daerah dengan mengacu pada standar nasional pendidikan.

\section{Di TPA dan KB}

Pendidikan nonformal juga menyelenggarakan pendidikan anak usia dini yang tidak termasuk jalur pendidikan formal dalam bentuk taman penitipan anak (TPA) dan kelompok bermain (KB) atau bentuk lain yang sederajat. TPA dan KB ini didirikan oleh masyarakat dan pemerintah membantu pengembangannya dalam bentuk pelatihan untuk pengelola dan dan untuk prasarananya. Penyelenggaraan TPA dan KB lebih mengarah pada pembinaan gizi dan kesehatan di samping menyelenggarakan permaianan edukatif. Oleh karena itu, sumber belajar yang tersedia adalah alatalat permainan termasuk untuk musik dan tidak jauh berbeda dengan taman kanak-kanak.

Pendidikan anak usia dini ( 0 - 6 tahun) di jalur pendidikan nonformal terdiri atas dua jenis yaitu TPA dan KB dan bentuk lain yang sederajat. TPA untuk anak berusia $0-<2$ tahun, $2-<4$ tahun, $4-<6$ tahun dan $\mathrm{KB}$ untuk anak berusia $2-<4$ tahun dan $4-<6$ tahun. Untuk mencapai tujuan pendidikannya, TPA dan KB membelajarkan anak mandiri dan bertanggung jawab dalam keseharian. Contohnya, anak-anak diajak untuk berani dan bisa melayani diri sendiri seperti pergi ke toilet sendiri, bisa memakai dan melepas kaus kaki dan sepatu, makan sendiri serta berhati-hati dan bertanggung jawab untuk menjaga barang bawaan pribadi pemelajar. Agar proses belajar dan pembelajaran dapat berlangsung mencapai tujuan, maka disediakan berbagai jenis permainan yang sesuai dengan tingkat perkembangan fisik, mental, dan emosi anak. Guru berfungsi mendampingi, mengawasi, dan membantu anak agar dapat melayani dirinya sendiri dalam bermain sambil belajar.

Untuk menciptakan iklim bermain sambil belajar atau belajar sambil bermain, ruangan ditata dengan berbagai gambar dan hiasan yang bermakna seperti fauna dan flora, pemandangan, dan bangunan sehingga menarik, memberikan rasa nyaman, dan aman. Di ruangan permainan terdapat alat-alat olahraga sederhana untuk mengembangkan kemampuan kinestetik seperti berenang dalam bola, ayunan, jungkitan, papan luncur, terowongan, dan mainan edukasi lainnya. Kegiatan belajar dilakukan dengan bercerita, tanya jawab, kunjungan ke lapangan, dan simulasi dengan memberikan kesempatan kepada anak berperan aktif.

TPA dan KB dapat mengembangkan sarana bermain sesuai dengan kemampuan penyelenggara sehingga terdapat juga sarana seperti ruang kelas dengan $A C$, ruang bermain, ruang komputer, ruang ulang tahun, ruang LCD/VCD/OHP, ruang pertemuan, perpustakaan, UKS/UKGS, mandi bola, kolam renang, serta tempat bermain luar ruangan. Semakin beraneka ragam sarana yang tersedia semakin memberi kemungkinan lebih banyak kepada pemelajar melakukan pilihan-pilihan permainan sesuai dengan minat, kesenangan, dan kemampuan anak.

Dengan gambaran keadaan TPA dan KB yang telah disampaikan, proses bermain sambil belajar dengan menggunakan berbagai sumber bermain dan belajar dilakukan dengan memperkenalkan anak pada berbagai jenis permainan yang sesuai dengan usianya dan membiarkan anak memilih jenis permainan yang disukainya. Pesan pelajaran disampikan melalui berbagai jenis permainan anak diberikan kebebasan memilih jenis permainan. Demikian juga ketika anak diperkenalkan anak menonton film, melakukan permainan elektronik, atau mendengarkan musik dan lagu, biarkan anak memilih film, permainan, musik, atau lagu sesuai dengan kesenangannya. Anak juga dapat diajak 
saling belajar satu sama lain dalam menggunakan alatalat permainan atau dalam bermain dengan tetap dalam pengawasan guru.

Meniru adalah salah satu ciri anak usia dini. Oleh karena itu, guru sebagai sumber belajar perlu memberikan teladan yang baik dalam menyapa, berbicara, duduk, bediri atau berjalan di depan anak-anak. Guru juga dapat mengajak anak bernyanyi bersama dan baris-berbaris untuk menanamkan disiplin dan kerja sama antaranak.

Di samping itu, di dalam ruangan terdapat berbagai gambar dan hiasan dinding serta dan di halaman/ pekarangan terdapat berbagai jenis bunga dan patungpatung binatang yang masing-masing mengandung pesan edukatif. Anak-anak hendaknya diajak mengamati lingkungan belajarnya sesuai dengan minatnya serta didorong untuk menceritakan hasil pengamatannya.

Dalam contoh-contoh kegiatan bermain dan belajar seperti diuraikan, prinsip-prinsip belajar dan membelajarkan berpusat pada anak telah diterapkan. Kebebasan memilih permainan yang edukatif serta mengamati lingkungan yang sesuai dengan minat dan kesenangan anak juga telah diberikan dalam tuntunan guru. Dengan demikian, prinsip-prinsip belajar berbasis aneka sumber juga telah dipraktikkan sejak pendidikan anak usia dini.

\section{Di Tempat Kursus dan Pelatihan}

Pendidikan nonformal juga mencakup kursuskursus dan tempat-tempat pelatihan yang bersifat khusus dilihat dari kemampuan dan keterampilan yang ingin dicapai, bahan kursus dan pelatihan, sumber belajar, dan pemelajarnya. Kursus dan pelatihan memerlukan sumber belajar yang spesifik disesuaikan dengan kemampuan atau keterampilan yang dicapai. Misalnya, kursus montir mobil, akan menggunakan sumber belajar yang berkaitan dengan mobil dalam bentuk cetakan dan peralatan praktek disesuaikan dengan kemajuan teknologi automotif. Demikian juga kursus menjahit memerlukan sumber belajar dalam bentuk cetakan dan peralatan menjahit dari teknologi yang sederhana sampai yang maju. Oleh karena banyaknya jenis kurus dan pelatihan yang masing-masing memiliki kekhususan sendiri, maka metode pembelajaran dan pengembangan sumber belajarnya tidak terlalu bervariasi serta telah terarah.

Dalam kursus belajar bahasa terdapat beberapa sumber belajar yang dapat dipergunakan untuk menguasai keterampilan mendengar, berbicara, membaca, dan menulis. Untuk mendengar, dapat mendengarkan kaset audio, menonton film atau mendengar guru atau teman berbicara. Untuk melatih berbicara, dapat dipraktikkan langsung dengan guru atau sesama teman, menggunakan laboratorium bahasa atau dengan menggunakan media interaktif berbantuan komputer. Itu berarti bahwa masih terdapat kemungkinan memberikan kebebasan kepada peserta kursus untuk belajar secara aktif dengan gaya belajarnya. Dalam kursus dan pelatihan keterampilan lain masih memungkinkan penerapan belajar dan membelajarkan berpusat kepada pemelajar dengan memberikan kesempatan kepada pemelajar, belajar sesuai dengan kecepatan dan minat belajarnya. Dalam konteks belajar dan membelajarkan yang demikian, pemelajar menempatkan dirinya lebih banyak sebagai perancang dan pengelola pembelajaran, pembimbing pemelajar ketika menghadapi kesulitan belajar, serta motivator pemelajar untuk belajar secara kreatif dan inovatif.

\section{Di PKBM}

Pendidikan nonformal yang jangkauannya lebih luas dan bersifat umum ialah pendidikan masyarakat yang dilakukan melalui Pusat Kegiatan Belajar Masyarakat (PKBM) yang didirikan, dikelola, dan dimanfaatkan oleh masyarakat. Di wilayah yang belum ada PKBM, pemerintah daerah membuat inisiatif untuk mendirikan dan mengembangkannya. Dalam menyelengarakan kegiatannya, PKBM dibantu dan diawasi oleh pemerintah melalui pemerintah daerah atau dinas pendidikan. PKBM memyelenggarakan kegiatan pendidikan (1) Bekerja dan Belajar Paket A(Kejar Paket A); (2) Bekerja dan Belajar Paket B (Kejar Paket B); (3) Bekerja dan Belajar Paket C (Kejar Paket C); (4) Pendidikan Anak Usia Dini (PAUD); (5) Kelompok Belajar Usaha (KBU); (6) Kelompok Usaha Pemuda Produktif; (6) Pemberdayaan Perempuan; (7) Keaksaraan Fungsional Dasar Dewasa; (8) Taman Bacaan Masyarakat.

Semua kegiatan yang diselenggarakan di PKBM seharusnya menggunakan TBM sebagai sumber belajar utama. Akan tetapi tidak jarang ditemukan kegiatan TBM kurang dikaitkan dengan kegiatan PKBM secara keseluruhan dan berbagai kegiatan belajar dan membelajarkan di PKBM tidak dikaitkan dengan TBM sebagai salah satu sumber belajar. Hal ini terjadi karena pengelolaan kegiatan TBM kurang dilakukan secara terpadu dan pembelajar di TBM belum menyadari peranan TBM sebagai salah satu komponen sistem belajar dan membelajarkan. Oleh karena itu, pembahasan berikut ini ialah bagaimana cara menggunakan TBM dalam mengembangkan pendekatan belajar berpusat kepada siswa dengan memanfaatkan aneka sumber belajar.

Secara umum, TBM di PKBM bertujuan membantu masyarakat mendapatkan dan menggunakan 
informasi dari berbagai sumber untuk dijadikan bahan dalam meningkatkan kemampuan dan keterampilannya dalam berbagai bidang khususnya yang berkaitan dengan berbagai program pembelajaran yang dilakukan di PKBM. TBM memiliki misi (a) menyediakan sumber informasi dalam bentuk cetakan dan noncetakan yang sesuai dengan kebutuhan masyarakat setempat; (b) menyediakan tenaga yang profesional dalam membimbing masyarakat mencari dan mendapatkan informasi dari aneka sumber; dan (c) mewujudkan masyarakat gemar belajar.

Dengan tujuan dan misi yang demikian, TBM di PKBM diharapkan dapat melaksanakan tugasnya dengan baik dalam (a) membantu penyelenggaraan kegiatan belajar yang dilakukan di PKBM; (b) memberikan informasi kepada masyarakat khususnya warga belajar PKBM tentang sumber belajar yang ada di TBM; (c) meningkatkan kesadaran maysarakat pentingnya belajar; (d) membantu masyarakat menggunakan berbagai sumber belajar; (e) meningkatkan minat baca masyarakat; dan (f) meningkatkan kemampuan membaca masyarakat. Tugas-tugas TBM ini menunjukkan, TBM pada umumnya memiliki peran yang strategis dalam mendorong tumbuh dan berkembangnya masyarakat gemar membaca menuju masyarakat gemar belajar sehingga terbentuklah masyarakat belajar yang berpendidikan.

Berkaitan dengan peranan TBM dalam proses belajar dan membelajarkan di PKBM, pengelolaan PKBM hendaknya dilakukan dengan pendekatan sistem dan semua komponen/ unit di PKBM memiliki keterkaitan dan ketergantungan satu sama lain secara sistemik. Dengan demikian, fungsi koordinasi, kolaborasi, dan sinergi yang dinamis sangat diperlukan. Hal teknis yang perlu dilakukan ialah pertama, sejak mulai mengembangkan TBM PKBM, pengadaan sarana dan prasarana sebagai sumber belajar seharusnya berdasarkan kebutuhan semua kegiatan belajar dan membelajarkan di PKBM di samping kebutuhan masyarakat sekitar. Jenis sumber belajar yang disediakan juga memperhatikan karakteristik warga belajar dan gaya belajarnya sehingga terdapat berbagai pilihan. Misalnya jenis dan isi koleksi bahan cetak dan noncetak mencakup semua informasi yang diperlukan dalam kursus dan pelatihan di PKBM. Alat belajar yang ada dapat dipergunakan secara visual, audio, dan audiovisual. Kedua, petugas TBM PKBM diikutsertakan dalam membuat dan mengembangkan rancangan pembelajaran untuk setiap kurusus dan pelatihan. Petugas TBM PKBM memberikan masukan bagaimana TBM PKBM dapat berperan serta secara bermakna dalam mewujudkan pembelajaran yang aktif, interaktif, kreatif, inovatif, efektif, efisien, dan menyenangkan. Ketiga, kegiatan pembelajaran dalam setiap kursus dan pelatihan dilakukan secara terintegerasi dengan kegiatan di TBM dalam arti ada kegiatan belajar dan membelajarkan dilakukan secara khusus di TBM PKBM. Keempat, petugas TBM memberikan bantuan bagaimana cara mencari, menemukan, dan menggunakan berbagai informasi yang dibutuhkan warga belajar untuk meningkatkan keterampilan belajarnya. Kelima, TBM PKBM menata ruangan semua sumber belajar yang ada secara rapi, praktis, menarik, dan menyenangkan sehingga memotivasi warga belajar dan pemelajar mengunjungi dan memanfaatkan semua sumber belajar serta mendorong mereka belajar terus menerus sepanjang hayat.

Di luar PKBM, terdapat juga TBM yang bukan dikelola oleh PKBM tetapi mandiri yang dikelola oleh warga masyarakat dan dipergunakan sebagai sumber informasi bagai masyarakat untuk meningkatkan kemampuan dan keterampilan di berbagai bidang. TBM ini juga dapat dikembangkan sebagai pusat sumber belajar yang memberikan kemudahan bagi masyarakat untuk belajar sesuai dengan gaya dan kemampuan belajarnya. Selain menyediakan berbagai jenis informasi dalam beraneka ragam tampilan (cetak dan noncetak), TBM ini dapat menyelenggarakan diskusi-diskusi kecil tentang berbagai topik yang menarik dan relevan dengan peningkatan pengetahuan masyarakat, menonton video pembelajaran bersama-sama, dan lain sebagainya. Dalam berinteraksi sosial demikian, warga masyarakat dapat saling belajar dan membelajarkan dengan berukar pikiran dan pengalaman. Dengan demikian, masyarakat dapat dilatih belajar secara mandiri dengan menggunakan aneka sumber belajar.

\section{Peranan Pembelajar, Pemelajar, dan Lembaga} Pendidikan

Pendekatan belajar berbasis aneka sumber seperti yang telah diuraikan mengacu pada cara belajar siswa aktif (student active learning) sebagaimana yang diharapkan dalam paradigma baru pendidikan. Dalam pendekatan ini, proses pembelajaran berpusat pada pemelajar yang menurut Knowles (1984) berarti memberikan pilihan kepada pemelajar di mana, kapan, dan bagaimana belajar; mengutamakan belajar daripada mengajar; meningkatkan tanggung jawab dan kegiatan pemelajar daripada pengawasan dan pemberian bahan dari pemelajar; mengembangkan kegiatan belajar ,dan penilaian yang mendorong pemelajar membangun pengetahuannya dengan melibatkan diri dalam masalahmasalah autentik berdasarkan pengalaman nyata, dan menggunakan umpan balik dan penilaian formal untuk memperbaiki metode pembelajaran dan pemelajaran. 
Pemelajar perlu menjadi prioritas dalam pembelajaran karena pemelajar yang akan menghadapi berbagai masalah dalam kehidupannya, menggunakan pengetahuan dan keterampilannya memecahkan masalah itu, serta berinteraksi dan bekerja sama dengan orang lain dalam mencari pemecahan berbagai persoalan di tempat dan di luar tempatnya bekerja di kemudian hari. Kemampuan yang demikianlah yang perlu dikembangkan mulai dari awal pembelajaran dan sepanjang hidup. Proses pembelajaran yang demikian, dapat dilakukan dengan berpusat kepada pemelajar, fleksibel, dan bermakna dengan menggunakan aneka sumber belajar dalam melaksanakan discovery learning, experiential learning, problem-based learning, inquiry learning, contextual learning, collaborative learning, atau cooperative learning. Semua model-model belajar ini juga dapat dan perlu diterapkan dalam proses belajar dan membelajarkan di pendidikan nonformal.

Berkaitan dengan pemanfaatan aneka sumber belajar, beberapa hal yang perlu diperhatikan oleh pembelajar, pemelajar, dan satuan pendidikan nonformal adalah sebagai berikut.

Pertama, pembelajar perlu (a) membuat dan mengembangkan desain pembelajaran dalam berbagai bentuk yang sesuai dengan tujuan pembelajaran yang ditetapkan; (b) menghubungkan sumber-sumber informasi, kegiatan belajar, tempat kegiatan, dan hasil belajar dengan kebutuhan dan kemampuan masing-masing pemelajar; (c) melaksanakan desain pembelajaran dengan lebih memberikan penekanan pada kemampuan proses belajar daripada hanya bahan pelajaran; (d) menyusun bahan pembelajaran dari berbagai sumber; (e) menyiapkan media dan alat bantu pembelajaran sesuai dengan model pembelajaran yang dibuat; (f) memberikan kesempatan dan kebebasan kepada pemelajar untuk belajar sesuai dengan gaya dan kecepatan belajarnya masing-masing; (g) memberikan dan bimbingan kepada pemelajar yang menghadapi kesulitan belajar; (h) memberikan motivasi kepada siswa untuk belajar dan memecahkan masalah dengan melakukan investigasi sumber informasi yang tepat; (i) menyiapkan alat evaluasi untuk mengukur hasil belajar; dan (j) terus menerus belajar meningkatkan kemampuan profesionalnya sehingga kreatif dan inovatif dalam membelajarkan.

Apabila melakukan kesepuluh kegiatan itu, dengan sendirinya pembelajar bukan lagi sebagai sumber informasi utama, tetapi berfungsi sebagai manajer kelas yang memiliki banyak informasi dalam berbagai media seperti film atau bahkan komputer (Coulson, 1967:1). Menurut Beswick (1977:20-21), peranan pembelajar menjadi pengajar menjadi sangat berkurang dan lebih berperan sebagai kolaborator dan pembimbing, bukan lagi memberikan perintah-perintah tetapi berpartisipasi dalam belajar.

Kedua, pemelajar perlu (a) menyadari pentingnya manfaat informasi dalam belajar; (b) mengetahui informasi dapat diperoleh dengan berbagai cara dan dari berbagai sumber; (c) giat mencari informasi secara sendiri-sendiri atau berkelompok; (d) mengetahui proses belajar dapat terjadi melalui interaksi dengan sumber belajar yang tepat; (e) terampil dalam mencari, memilah, memilih informasi yang tepat untuk mencapai tujuan belajar tertentu; (f) berpikir kritis dan objektif dalam menanggapi berbagai informasi yang ada; (g) membangun pengetahuan baru berdasarkan informasi yang dkumpulkan dan dianalisis; (h) menggunakan pengetahuan dan pengalaman baru dalam memecahkan masalah dalam kehidupan yang nyata; dan (i) mengkomunikasikan pengetahuan baru yang diperoleh secara lisan dan tertulis.

Apabila melakukan kegiatan seperti disebutkan di atas, pemelajar berarti berpartisipasi aktif dalam proses belajar sehingga memiliki dan mengembangkan kemampuan belajar mandiri dan memahami bahan yang perlu dipelajari, informasi yang diperlukan, sumber informasi, cara memperoleh dan mengolah informasi, dan menggunakannya untuk membangun pengetahuan baru sesuai dengan teori konstruktivisme.

Ketiga, satuan pendidikan nonformal perlu (a) membuat dan mengembangkan kurikulum yang berbasis aneka sumber belajar; (b) menyediakan aneka sumber belajar mulai dari yang paling sederhana sampai ke yang berbasis teknologi informasi dan komunikasi yang maju; (c) menyediakan bahan dan alat untuk pembelajar merancang, membuat, dan mengembangkan media pembelajaran; (d) memberikan kebebasan dan kesempatan kepada pembelajar untuk kreatif membuat dan mengembangkan model-model pembelajaran; (e) memberikan kebebasan dan kesempatan kepada pemelajar memperkaya pengetahuannya dengan menggunakan aneka sumber belajar; (f) meningkatkan kemampuan profesional dan pedagogi pembelajar dengan berbagai bentuk pendidikan dan pelatihan; dan ( $\mathrm{g}$ ) menyediakan tenaga, sarana, dan prasarana, serta dana untuk keperluan belajar dan membelajarkan berbasis aneka sumber.

Dengan melakukan kegiatan di atas, diharapkan pelaksanaan belajar dan membelajarkan memberikan kesempatan belajar kontekstual yang menempatkan belajar dalam konteks yang relevan dan bermakna, memberikan lingkungan belajar yang mendukung, dan mengenal berbagai nilai dan keanekaragaman untuk belajar lebih mendalam dalam komitmen yang dinamis. 


\section{KESIMPULAN}

Perkembangan dalam psikologi, pedagogi, dan andragogi di satu pihak dan perkembangan teknologi informasi dan komunikasi di pihak lain telah mengakibatkan pergeseran paradigma tentang pendidikan. Salah satu ciri paradigma pendidikan baru ialah penyelenggaraan pendidikan khsusnya belajar dan membelajarkan berorientasi pada pemelajar dengan berbagai karakteristiknya.

Perbedaan karakteristik pemelajar mengakibatkan masing-masing individu memiliki gaya belajar yang mungkin berbeda satu sama lain. Perbedaan gaya belajar ini meliputi teknik, tempat, waktu, dan lingkungan belajar. Belajar berbasis aneka sumber, yang memperhatikan karakteristik termasuk gaya belajar masing-masing individu pemelajar merupakan salah satu pendekatan yang dapat memenuhi kebutuhan belajar pemelajar.

Pendekatan belajar berbasis aneka sumber dapat diterapkan di berbagai lingkungan belajar, tidak hanya di lingkungan lembaga pendidikan tetapi juga di berbagai organisasi lain serta di tengah-tengah masyarakat. Pemelajar dapat memilih sumber belajar yang tersedia di lingkungannya sesuai dengan gaya belajar- nya dan tidak harus bergantung pada sumber belajar yang berbasis teknologi.

Keberhasilan penggunaan pendekatan belajar berbasis aneka sumber tergantung pada kemampuan pembelajar membuat desain pembelajaran yang memungkinkan pemelajar menggunakan berbagai sumber belajar untuk mencapai tujuan pembelajaran. Dalam pelaksanaannya, pembelajar berperan membantu pemelajar yang mengalamai kesulitan belajar, serta menyediakan sumber-sumber belajar yang diperlukan pemelajar. Di samping itu, pemelajar harus berperan aktif dalam mengidentifikasi sumber-sumber belajar yang sesuai dengan gaya belajarnya, berinteraksi dengan sumber belajar yang dipilih dengan mengumpulkan dan mengolah informasi untuk membangun pengetahuan atau keterampilannya. Untuk memenuhi aneka sumber belajar yang diperkukan pemelajar, lembaga pendidikan perlu proaktif menyediakan berbagai sumber belajar dengan memperhatikan tujuan pembelajaran serta gaya belajar pemelajar. Pembelajar, pemelajar, dan lembaga pendidikan perlu bekerja sama dalam menerapakan pendekatan belajar berbasis aneka sumber secara berhasil guna dan tepat guna.

\section{DAFTAR PUSTAKA}

Anderson, O.W. \& Krathwohl, D.R. (2001). A taxonomy for learning, teaching, and assessing: A revision of Bloom's taxanomy of educational objectives. New York: Addison Wesley Longman.

Barbara, S. (1998). Making instructional design decisions. Apper Saddle River, N.J.: Merill.

Belt, S. (1997). Emerging vision of an information age education. Diakses pada tanggal 15 November 2011 dari situs http://www.pnx.com/gator.

Beswick, N. (1977). Resource-based learning. London: Heinemann Educational Books.

Beswick, N. W. (1977). Resource-based learning. London: Heinemann

Brandes \& Ginnis. (1986). A guide to student centered learning. Oxford: Blackwell

Departeman Pendidikan Nasional. (2007). Kerangka dasar kurikulum PAUD. Jakarta:

Dorrell, J. (1993). Resource-based learning: Using open and flexible learning resources for continous development. Berkshire: McGraw-Hill Book Company Europe.

Edwards, R. (2001). Meeting individual learner needs: power, subject, subjection. In C. Paechter, M. Preedy, D. Scott, and J. Soler (Eds.), Knowledge, Power and Learning. London: SAGE.

Eraut, M. (2001). Educational technology: Definition and conceptual background. Dalam International ensyclopedia of educational technology diedit oleh Tjeerd Plomp dan Donald P. Ely. Kidlington, Oxford: Pergamon.

Gardner, H. (2004). Multiple intelligences. Diakses pada tanggal 15 November 2011 dari situs http:// tip.psychology.org/gardner.html.

Harianti, D. (2007). Naskah akademik kajian kebijakan kebijakan kurikukum. Jakarta: Pusat Pusat Kurikulum, Badan Penelitian dan Pengembangan Pendidikan, Deparemen Pendidikan Nasional:

Hill, J. R., \& Hannafin, M. J. (2001). The resurgence of resource-based learning. Educational Technology, Research and Development, Vol. 49(3), 37-52.

Januszewski, A. (2002). Educational technology: The development of a concept. Englewood, Colorado: Libraries Unlimited. 
Knowles, M. S., et .al. (1984). Andragogy in Action. Applying modern principles of adult education, San Francisco: Jossey Bass.

Lea, S. J., Stephenson, D. \& Troy, J. (2003). Higher Education Students' Attitudes to Student Centred Learning: Beyond 'educational bulimia'. Studies in higher education, Volume 28 (3), hlm. 321334.

Meyer, R. (2003). Learning and instruction. New Jersey: Pearson Education, Inc.

O'Sullivan, M. (2003). The reconceptualisation of learner-centred approaches: A Nambian case study. International Journal of Educational Development. In Press.

O'Neil, G. \& McMahon, T. (2005) Student-centred learning: What does it mean for students and lecturers?. Dalam Emerging Issues in the Practice of University Learning and Teaching. All Ireland Society for Higher Education, Dublin.

O'Neil, G. \& McMahon, T. (2005). Student-centred learning: What does it mean for students and lecturers? in Emerging Issues in the Practice of University Learning and Teaching. All Ireland Society for Higher Education, Dublin.

Reigeluth, C. M. (1999). Introduction. Dalam C. M. Reigeluth (Ed.) What is instructional-design theory and how is it changing hlm. 5-30. Mahwah, $\mathrm{NJ}$ : Lawrence Erlbaum Associates, Inc.

Reigeluth, C.M. \& Garfinkle, J.G. (1994). Systemic change in education. Englewood Cliffs, N.J.:
Educational Technology Publications.

Reigeluth, C.M. (Ed.). (1987). Instructional theories in action: Lessons illustrating selected theories and models. Hillsdale, N.J.: Lowrence Erlbaum Associates, Inc.

Reiser, R.A. \& Dempsey, J.V. (2002). Trends and issues in instructional design and technology. London: Pearson Education.

Richey, R.C., Klein, J.D., \& Tracey, M.W. (2011). The instructional design knowledge base: Theory, research, and practice. New York: Routledge

Rosen, D.L., Carrier, L.M., Cheever, N.A. (2010). Rewired: Understanding the generation and the way they learn. New York: Palgrave Macmillan.

Schank, R.C., Berman, T.R., \& Macphers0n, K. A. (1999). Dalam C. M. Reigeluth (Ed.) Learning by Doing. Instructional-design theories and models, hlm. 161-182. Mahwah, NJ: Lawrence Erlbaum Associates, Inc.

Santoso, S. (2002). Pendidikan anak usia dini. Jakarta: Yayasan Citra Pendidikan

Vygotsky, L. S.(2004) Social Development Theory. Diakses pada tanggal 19 November 2011 dari situs http://tip.psychology.org/vygotksky.html

Zukas, M. \& Malcom, J. (2001). Pedagogies for lifelong learning: Building bridges or building walls? Working papers of the Global Colloquium on Supporting Lifelong Learning, Milton Keynes, UK: Open University. 